\title{
Article \\ Novel Global-MPPT Control Strategy Considering the Variation in the Photovoltaic Module Output Power and Loads for Solar Power Systems
}

\author{
Shiue-Der Lu ${ }^{1} \mathbb{D}$, Chang-Hua Lin ${ }^{2} \mathbb{D}$, Liang-Yin Huang ${ }^{3}$, Yu-Lin Lee ${ }^{2} \mathbb{D}$, Hwa-Dong Liu ${ }^{4} *{ }^{*}$, Pin-Chao Liao ${ }^{4}$, \\ Guo-Jyun Gao ${ }^{4}$ and Chih-Ming $\mathrm{Hsu}^{3}$
}

check for

updates

Citation: Lu, S.-D.; Lin, C.-H.; Huang,

L.-Y.; Lee, Y.-L.; Liu, H.-D.; Liao, P.-C.;

Gao, G.-J.; Hsu, C.-M. Novel

Global-MPPT Control Strategy

Considering the Variation in the

Photovoltaic Module Output Power

and Loads for Solar Power Systems.

Processes 2022, 10, 367. https://

doi.org/10.3390/pr10020367

Academic Editor: Ambra

Giovannelli

Received: 18 January 2022

Accepted: 11 February 2022

Published: 14 February 2022

Publisher's Note: MDPI stays neutral with regard to jurisdictional claims in published maps and institutional affiliations.

Copyright: (C) 2022 by the authors. Licensee MDPI, Basel, Switzerland. This article is an open access article distributed under the terms and conditions of the Creative Commons Attribution (CC BY) license (https:// creativecommons.org/licenses/by/ $4.0 /)$
1 Department of Electrical Engineering, National Chin-Yi University of Technology, Taichung 411, Taiwan; sdl@ncut.edu.tw

2 Department of Electrical Engineering, National Taiwan University of Science and Technology, Taipei 106, Taiwan; link@mail.ntust.edu.tw (C.-H.L.); d10807005@mail.ntust.edu.tw (Y.-L.L.)

3 Graduate Institute of Manufacturing Technology, National Taipei University of Technology, Taipei 106, Taiwan; t104569011@ntut.edu.tw (L.-Y.H.); jmshiu@ntut.edu.tw (C.-M.H.)

4 Undergraduate Program of Vehicle and Energy Engineering, National Taiwan Normal University, Taipei 106, Taiwan; angus01179@gmail.com (P.-C.L.); j0905756708@gmail.com (G.-J.G.)

* Correspondence: hdliu@ntnu.edu.tw; Tel.: +886-2-77495953

\begin{abstract}
This research proposed a novel global maximum power point tracking (global-MPPT) algorithm. The proposed algorithm eliminates the perturbation and observation (P\&O) technique disturbance problem that the power point will be stuck at the local peak power point under a partial shading condition (PSC). The proposed global-MPPT algorithm detects the photovoltaic module (PV-M) environment irradiance level by the relationship between the output power and voltage of the PV-M. In the proposed algorithm, the important parameter $w$ is determined by the PV-M output power and irradiance level, which is also the compensation parameter that corresponds to the relationship of temperature. The proposed global-MPPT algorithm is aimed to predict the best duty cycle of the global-MPPT based on the irradiance level, parameter $w$, PV-M output voltage, and load, and then achieve the maximum power point (MPP) quickly and accurately. The measurement results under UIC and PSC verify that the proposed global-MPPT technique performs better than the particle swarm optimization (PSO) and P\&O techniques. This research contributes to the proposed method that can find the global-MPP in time based on the irradiance level, temperature, and load.
\end{abstract}

Keywords: partial shading condition; perturbation and observation algorithm; particle swarm optimization algorithm; solar power system

\section{Introduction}

Industrial development has affected the Earth's climate and led to the greenhouse effect. The application of renewable energy can reduce the impact of the greenhouse effect on the living environment. Therefore, renewable energy is an important research topic for industrial development. Renewable energy has a wide range of sources, including wind power, hydropower, geothermal power, biomass power, and solar power. This research focused on solar power generation (SPG) systems. SPG is widely used in daily life, including electric vehicle charging stations [1], electric vehicles [2], energy storage systems [3], street lights [4], electric water heaters [5], artificial satellites [6], household electricity [7-10], heating equipment [11,12], renewable energy hybrid systems [13,14], etc.

The photovoltaic module (PV-M) used in SPG is susceptible to the effects of temperature $(\mathrm{T})$ and irradiance level $(\mathrm{G})$, thereby reducing system efficiency $[15,16]$. Therefore, this study focused on the analysis and research of the SPG maximum power point (MPP). The maximum power point tracking (MPPT) technique has been frequently used in SPG [17], and Kumar et al. discussed the hill climbing (HC) algorithm architecture as being cheap 
and simple to implement, and that after comparing new power point with old power point, MPPT can be executed [18]. Ji et al. proposed a new method of particle swarm optimization (PSO), through which the particles converge to reach the MPP [19]. Ji et al. used the new annealing and particle substitute, the Gaussian PSO (G-PSO) method, to reach the MPP [20]. Liu et al. reorganized the three power point technique, then searched for the MPP [21]. Liu et al. discussed a provisional stopped operating strategy and the three power point method for a PV system [22]. Saito et al. developed the eliminated MPPT oscillation method for solar power systems and confirmed it was feasible by the dynamic I-V curve [23]. Castaño et al. discussed the bionic bee MPPT technique for solar power systems using a boost converter [24]. Avila et al. used a deep learning model and reinforcement learning MPPT control for SPG [25]. Subudhi et al. studied an incremental PID MPPT controller for PV systems that could maintain a stable system under changing weather [26]. Singh et al. implemented the flying squirrel search optimization MPPT technique. This technique's MPPT speed is fast and improves the SPG system of efficiency [27]. Chang et al. developed a time-based MPPT circuit for a PV cell that can regulate the operation frequency and check the irradiance level function [28]. Zhang et al. used the non-periodic perturbation MPP capturing algorithm for solar power systems to reduce the actuating point vibration and increase system performance [29]. Pradhan et al. proposed modified incursive weed optimization and the perturbation and observation (P\&O) MPPT control technique suitable for harsh weather [30]. Barth et al. discussed the ripple correlation control (RCC) MPPT algorithm with high stability, efficiency, and accuracy [31].

This research proposed a novel global maximum power point tracking (global-MPPT) algorithm to analyze the relationship between the PV-M output voltage $\left(V_{p v-m}\right)$, output power $\left(P_{p v-m}\right)$, temperature $(\mathrm{T})$, and irradiance level $(\mathrm{G})$. The PV-M was connected to the load $\left(R_{o}\right)$ by the boost converter. The corresponding beeline was drawn, and the proposed global-MPPT algorithm was represented by a mathematical equation. The proposed globalMPPT algorithm can calculate the irradiance level and parameter $w$ according to the equations, where the parameter $w$ is the compensation parameter that corresponds to the relationship of temperature; the proposed global-MPPT algorithm took into account irradiance level $(\mathrm{G})$, parameter $w$, PV-M output voltage $\left(V_{p v-m}\right)$, and load $\left(R_{o}\right)$ to achieve the global-MPPT duty cycle, and it could capture the MPP under a uniform irradiance condition (UIC) and partial shading condition (PSC).

Some recent MPPT algorithms need to study the PV-M specifications for characterization before usage [32-35]. For example, Sutikno et al. discussed the MPPT algorithm based on fuzzy control, where the maximum and minimum values of fuzzy control were defined by the PV-M's specification, and the fuzzy control carried out the fuzzification and rule-base analysis, the defuzzification calculation, and then estimated the optimal MPP [32]. Allahabadi et al. implemented the artificial neural network MPPT control. This algorithm needs the amount and specification of the PV-M to determine the voltage and current generated by irradiation and temperature. After the data collection and training, the optimal MPP was found [33]. Kumar et al. developed the intelligent monkey king evolution MPPT algorithm. At first, this algorithm should obtain the PV-M specification to identify the range of the MPP corresponding to the irradiation and temperature. Plenty of small monkeys were sent to find the PV characteristic curve and then reported to the monkey king. The monkey king gave the MPPT orders to the small monkeys to reach the MPP [34]. Obukhov et al. discussed the classic PSO algorithm. This algorithm needs to ensure the specification of the PV-M to set the operation area of the particles and adjust fitness value and best position, and then reach the MPP [35]. The proposed global-MPPT algorithm also needs to study the PV-M specifications for characterization before usage.

In summary, the proposed global-MPPT algorithm greatly improved the inefficiency of the PSO and P\&O techniques. First, the proposed global-MPPT algorithm could accurately capture the MPP under UIC. Second, at a steady-state irradiance level, the actuating point could accurately capture the MPP without oscillating. Third, during radically varied 
irradiance levels, this actuating point could capture the MPP without diverging. Lastly, under PSC, the actuating point could also capture the global MPP.

The proposed global-MPPT algorithm as well as the PSO and P\&O algorithms were measured, compared, and then verified. Under UIC and PSC, the MPPT efficiency of the proposed global-MPPT algorithm is better than that of the PSO and P\&O algorithms. Under PSC, the proposed global-MPPT algorithm overcomes the problem that the actuating point will be trapped in the local MPP, which causes power loss.

Table 1 shows the property comparison of four algorithms. The MPPT speed of the proposed algorithm under UIC is higher than the $\mathrm{P} \& \mathrm{O}$ and RCC algorithms. The MPPT speed of the proposed algorithm under PSC is better than the P\&O, PSO, and RCC algorithms. The MPPT efficiency of the proposed algorithm under PSC is better than the $\mathrm{P} \& \mathrm{O}, \mathrm{PSO}$, and RCC algorithms.

Table 1. Property comparison of four algorithms.

\begin{tabular}{ccccccccc}
\hline \multirow{2}{*}{ Algorithm } & Parameters & Complexity & Number of & \multicolumn{2}{c}{ MPPT Speed } & \multicolumn{2}{c}{ MPPT Efficiency } \\
\cline { 7 - 9 } & & & Sensors & Under UIC & Under PSC & Under UIC & Under PSC \\
\hline Proposed & Necessary & Medium & Four & Rapid & Rapid & High & High \\
\hline P\&O [16] & Not necessary & Very low & Two & Slow & Slow & High & Low \\
\hline PSO [20] & Necessary & Medium & Two & Rapid & Medium & High & Medium \\
\hline RCC [31] & Not necessary & Low & Two & Medium & Slow & High & Medium \\
\hline
\end{tabular}

The P\&O, PSO, and RCC algorithms only need two sensors, but they cannot perform effectively under UIC and PSC, simultaneously (as shown in Table 1). By contrast, the proposed global-MPPT algorithm has both high efficiencies under UIC and PSC. However, four sensors are needed in the proposed algorithm, where the sensors are for collecting PV-M output voltage $\left(V_{p v-m}\right)$, PV-M output current $\left(I_{p v-m}\right)$, power converter output voltage $\left(V_{o}\right)$, and power converter output current $\left(I_{o}\right)$. Through these signals, the proposed globalMPPT algorithm can calculate the duty cycle corresponding to the global MPP, where $V_{o}$ and $I_{o}$ are to calculate load $\left(R_{o}\right)$. If the sensors of $V_{o}$ and $I_{o}$ are replaced by an impedance sensor, the sensors of the proposed global algorithm can be reduced to three.

The remainder of this paper is organized as follows: Section 2 describes the particle swarm optimization and perturbation and observation algorithms; the proposed global maximum power point tracking algorithm is presented in detail in Section 3; Section 4 presents the experimental results, while Section 5 includes conclusions and suggests directions for future work.

\section{Particle Swarm Optimization and Perturbation and Observation Algorithms}

\subsection{Particle Swarm Optimization Algorithm}

The PSO algorithm [20] is an artificial intelligence algorithm developed based on flocking behavior in birds. The algorithm first initializes the particle swarm, including the random position and the random speed. Second, the algorithm evaluates the fitness of each particle. Third, each particle of this algorithm is compared with other particles. The fitness value and the position are comparative standards, including the fitness value and the best position that the particle has ever experienced. If finding better fitness value and position, the algorithm will take this particle as the best position and fitness value. Fourth, each particle of this algorithm is compared with the other particles again. The fitness value and the position are comparative standards, including the fitness value and the global best position that the particles have ever experienced. If finding the best fitness value and the global best position, the algorithm then resets the global best position. Finally, the PSO algorithm continuously changes the speed and position of the particles and then repeats this estimation to reach the optimal value. However, this algorithm has some shortcomings, one of which is that the algorithm's continuous iterative estimation is time- 
consuming and cannot reach the MPP in time, causing low efficiency during the iterative estimation process.

\subsection{Perturbation and Observation Algorithm}

The P\&O algorithm [16,36] is widely used by researchers due to its low cost and easy implementation. This algorithm is based on the PV-M $P_{p v-m}-V_{p v-m}$ characteristic curve. First, the P\&O algorithm detects the slope of the PV-M output power and PV-M output voltage. Second, when the slope changes, the P\&O algorithm adjusts the duty cycle for performing MPPT to reach the MPP.

However, this algorithm has the following shortcomings: (1) under the partial shading condition (PSC), the actuating point can become stuck at the local peak power point without escape [37]; (2) at a steady-state irradiance level, the actuating point will vibrate near the MPP [21]; (3) with the rapid change in irradiance levels, the actuating point cannot capture the MPP in time [22]; (4) the actuating point is close to the MPP, and the convergence speed is slow [22].

\section{Proposed Global Maximum Power Point Tracking Algorithm}

This study proposed a new global-MPPT algorithm that can track the MPP in time. The proposed global-MPPT algorithm can avoid the drawbacks of the P\&O and PSO algorithms, and then enhance system performance. The proposed global-MPPT algorithm considers the relationships among $V_{p v-m}, I_{p v-m}, R_{p v-m}$, and the load, and then calculates the PV-M's irradiance level (G) and temperature (T). Furthermore, the proposed global-MPPT algorithm calculates the duty cycle at the MPP and then drives the power converter to reach the MPP.

Figure 1 displays the single PV-M that was used during the experiment. This single PV-M used a Chroma PV-M simulator (model number 62020H-150S). At irradiance level (G) $1000 \mathrm{~W} / \mathrm{m}^{2}$ and temperature (T) $25^{\circ} \mathrm{C}, \mathrm{PV}-\mathrm{M} V_{o c}=44.95 \mathrm{~V}, \mathrm{I}_{S C}=8.64 \mathrm{~A}, V_{M P P}=36.95 \mathrm{~V}$, $I_{M P P}=8.12 \mathrm{~A}$, and $P_{M P P}=300 \mathrm{~W}$ (as shown in Table 2). Figure 1a illustrates the PV-M $I_{p v-m^{-}}$ $V_{p v-m}$ characteristic curve graph at temperature $25{ }^{\circ} \mathrm{C}$ and the irradiance levels $200 \mathrm{~W} / \mathrm{m}^{2}$, $400 \mathrm{~W} / \mathrm{m}^{2}, 600 \mathrm{~W} / \mathrm{m}^{2}, 800 \mathrm{~W} / \mathrm{m}^{2}$, and $1000 \mathrm{~W} / \mathrm{m}^{2}$, respectively. Figure $1 \mathrm{~b}$ shows the PV-M $P_{p v-m}-V_{p v-m}$ characteristic curve graph at a temperature of $25^{\circ} \mathrm{C}$ and the irradiance levels $200 \mathrm{~W} / \mathrm{m}^{2}, 400 \mathrm{~W} / \mathrm{m}^{2}, 600 \mathrm{~W} / \mathrm{m}^{2}, 800 \mathrm{~W} / \mathrm{m}^{2}$, and $1000 \mathrm{~W} / \mathrm{m}^{2}$, respectively.

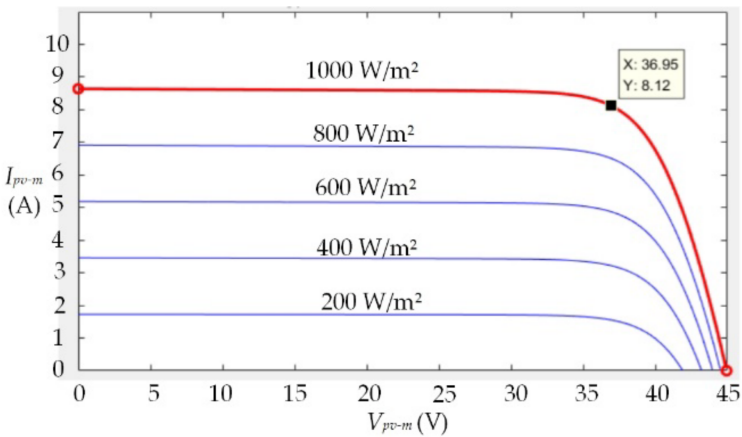

(a)

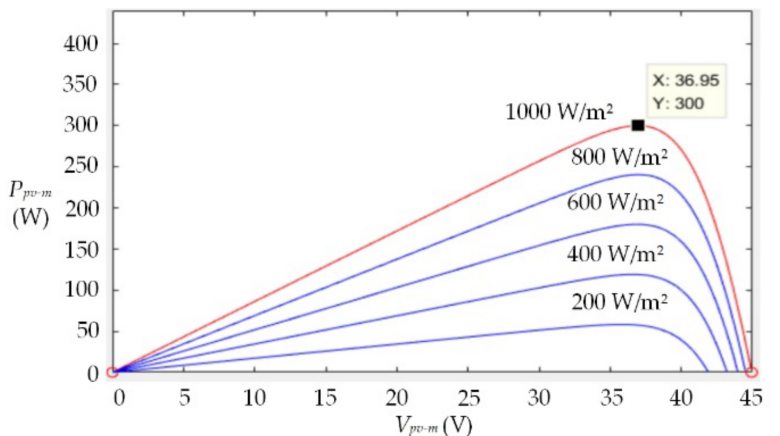

(b)

Figure 1. The characteristic curve graph of a single PV-M with MATLAB under $\mathrm{T}=25$ degrees and $\mathrm{G}$ of $200 \mathrm{~W} / \mathrm{m}^{2}, 400 \mathrm{~W} / \mathrm{m}^{2}, 600 \mathrm{~W} / \mathrm{m}^{2}, 800 \mathrm{~W} / \mathrm{m}^{2}, 1000 \mathrm{~W} / \mathrm{m}^{2}$, respectively. (a) PV-M $I_{p v-m}-V_{p v-m}$ characteristic curves. (b) PV-M $P_{p v-m}-V_{p v-m}$ characteristic curves. 
Table 2. The parameters of the photovoltaic module.

\begin{tabular}{cc}
\hline Parameter & Value \\
\hline PV-M open circuit voltage $\left(V_{o c}\right)$ & $44.95 \mathrm{~V}$ \\
\hline PV-M short circuit current $\left(I_{s c}\right)$ & $8.64 \mathrm{~A}$ \\
\hline PV-M maximum power point voltage $\left(V_{M P P}\right)$ & $36.95 \mathrm{~V}$ \\
\hline PV-M maximum power point current $\left(I_{M P P}\right)$ & $8.12 \mathrm{~A}$ \\
\hline PV-M maximum power $\left(P_{M P P}\right)$ & $300 \mathrm{~W}$ \\
\hline PV-M temperature coefficient of $V_{o c}$ & $-0.36901 \mathrm{~V} /{ }^{\circ} \mathrm{C}$ \\
\hline PV-M temperature coefficient of $I_{S C}$ & $0.06099 \mathrm{~A} /{ }^{\circ} \mathrm{C}$ \\
\hline
\end{tabular}

The relationship among PV-M $P_{p v-m}, V_{p v-m}$, and $R_{p v-m}$ is as follows:

$$
R_{p v-m}=\frac{V_{p v-m}^{2}}{P_{p v-m}}
$$

First, this study analyzed the PV-M $I_{p v-m}-V_{p v-m}$ characteristic curves as in Figure $1 \mathrm{a}$ and PV-M $P_{p v-m}-V_{p v-m}$ characteristic curves as in Figure $1 \mathrm{~b}$ and used Microsoft Excel to draw the relationship among $V_{p v-m}, P_{p v-m}$, temperature, and irradiance level beelines (as shown in Figure 2). Figure 2 demonstrates that twenty beelines were drawn to show the relationship among $V_{p v-m}, P_{p v-m}$, temperature, and irradiance level, where the temperatures $(\mathrm{T})$ are from $10{ }^{\circ} \mathrm{C}$ to $60{ }^{\circ} \mathrm{C}$, and the irradiance levels $(\mathrm{G})$ are $50 \mathrm{~W} / \mathrm{m}^{2}, 100 \mathrm{~W} / \mathrm{m}^{2}, 150 \mathrm{~W} / \mathrm{m}^{2}, 200 \mathrm{~W} / \mathrm{m}^{2}$, $250 \mathrm{~W} / \mathrm{m}^{2}, 300 \mathrm{~W} / \mathrm{m}^{2}, 350 \mathrm{~W} / \mathrm{m}^{2}, 400 \mathrm{~W} / \mathrm{m}^{2}, 450 \mathrm{~W} / \mathrm{m}^{2}, 500 \mathrm{~W} / \mathrm{m}^{2}, 550 \mathrm{~W} / \mathrm{m}^{2}, 600 \mathrm{~W} / \mathrm{m}^{2}$, $650 \mathrm{~W} / \mathrm{m}^{2}, 700 \mathrm{~W} / \mathrm{m}^{2}, 750 \mathrm{~W} / \mathrm{m}^{2}, 800 \mathrm{~W} / \mathrm{m}^{2}, 850 \mathrm{~W} / \mathrm{m}^{2}, 900 \mathrm{~W} / \mathrm{m}^{2}, 950 \mathrm{~W} / \mathrm{m}^{2}$, and $1000 \mathrm{~W} / \mathrm{m}^{2}$, respectively. The Beeline-1 to Beeline-20 were depicted PV-M output power $\left(P_{p v-m}\right)$ that the PV-M output maximum power $\left(P_{M P P}\right)$.The mathematical model for the twenty beelines could be approximated as the following quadratic equation:

$$
P_{p v-m}=x_{1} \cdot V_{p v-m}^{2}+y_{1} \cdot V_{p v-m}+z_{1}
$$

where $x_{1}, y_{1}$, and $z_{1}$ are parameters. Equation (2) shows the relationship between the parameters of $x_{1}, y_{1}$, and $z_{1}$, irradiance level, and temperature, as shown in Table 3 .

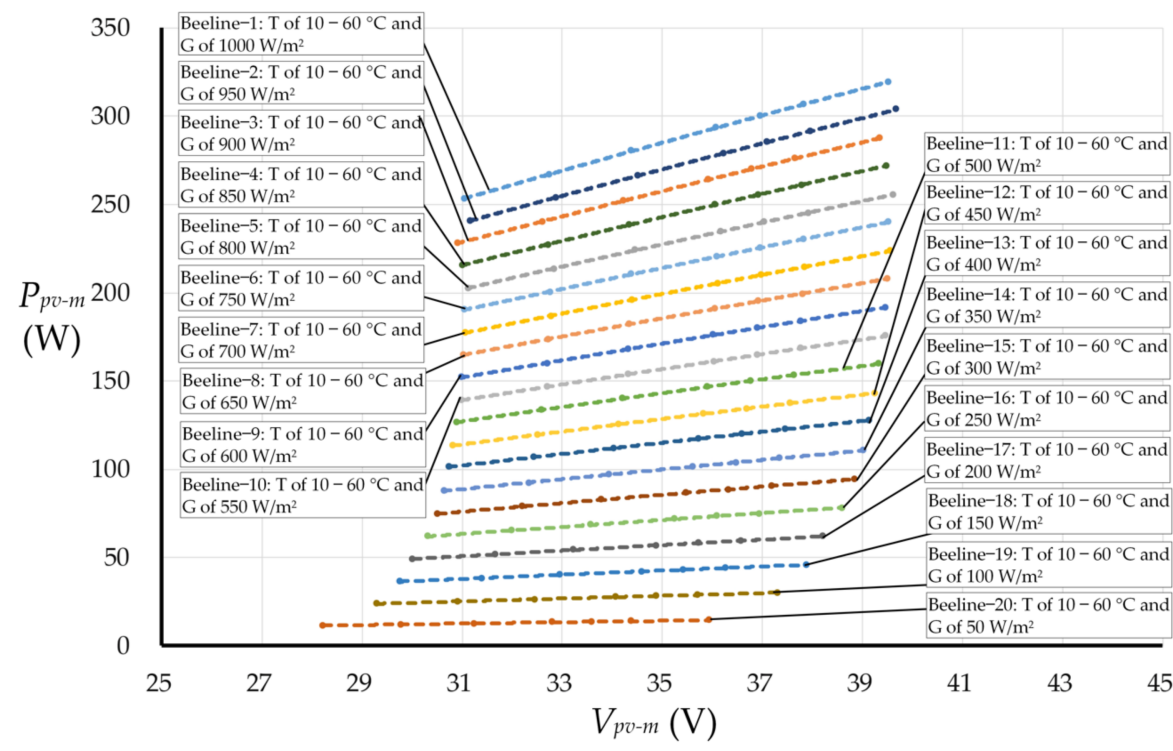

Figure 2. Relationship between $V_{p v-m}, P_{p v-m}$, temperature (T), and irradiance level (G). 
Table 3. Relationship between the $x_{1}, y_{1}$, and $z_{1}$ parameters, irradiance level, and temperature.

\begin{tabular}{|c|c|c|c|c|}
\hline \multirow{2}{*}{$\begin{array}{l}\text { Irradiance Level } \\
\qquad\left(\mathrm{W} / \mathrm{m}^{2}\right)\end{array}$} & \multirow{2}{*}{ Temperature $\left({ }^{\circ} \mathrm{C}\right)$} & \multicolumn{3}{|c|}{ Parameter } \\
\hline & & $x_{1}$ & $y_{1}$ & $z_{1}$ \\
\hline 1000 & $10-60$ & -0.0432 & 10.85 & -41.88 \\
\hline 950 & $10-60$ & -0.0408 & 10.275 & -39.81 \\
\hline 900 & $10-60$ & -0.0392 & 9.81 & -37.69 \\
\hline 850 & $10-60$ & -0.0369 & 9.25 & -35.64 \\
\hline 800 & $10-60$ & -0.0344 & 8.66 & -33.50 \\
\hline 750 & $10-60$ & -0.0324 & 8.15 & -31.47 \\
\hline 700 & $10-60$ & -0.0302 & 7.59 & -29.32 \\
\hline 650 & $10-60$ & -0.0281 & 7.06 & -27.25 \\
\hline 600 & $10-60$ & -0.0260 & 6.52 & -25.13 \\
\hline 550 & $10-60$ & -0.0238 & 5.97 & -23.01 \\
\hline 500 & $10-60$ & -0.0218 & 5.45 & -20.94 \\
\hline 450 & $10-60$ & -0.0196 & 4.89 & -18.76 \\
\hline 400 & $10-60$ & -0.0178 & 4.40 & -16.98 \\
\hline 350 & $10-60$ & -0.0155 & 3.82 & -14.70 \\
\hline 300 & $10-60$ & -0.0133 & 3.27 & -12.54 \\
\hline 250 & $10-60$ & -0.0112 & 2.73 & -10.38 \\
\hline 200 & $10-60$ & -0.0091 & 2.18 & -8.24 \\
\hline 150 & $10-60$ & -0.0068 & 1.63 & -6.11 \\
\hline 100 & $10-60$ & -0.0046 & 1.09 & -3.99 \\
\hline 50 & $10-60$ & -0.0024 & 0.55 & -1.93 \\
\hline
\end{tabular}

$V_{p v-m}^{\mathrm{G}}$ is determined via Equation (3), as follows:

$$
V_{p v-m}^{\mathrm{G}}=\frac{-y_{1}+\sqrt{y_{1}^{2}-4 \cdot x_{1} \cdot\left(z_{1}-P_{p v-m}\right)}}{2 \cdot x_{1}}
$$

Different irradiance levels correspond to different parameters of $x_{1}, y_{1}$, and $z_{1}$. First, Equation (3) and Table 3 were used to calculate 20 sets of $V_{p v-m}^{\mathrm{G}}$ of the irradiance levels $50 \mathrm{~W} / \mathrm{m}^{2}, 100 \mathrm{~W} / \mathrm{m}^{2}, 150 \mathrm{~W} / \mathrm{m}^{2}, 200 \mathrm{~W} / \mathrm{m}^{2}, 250 \mathrm{~W} / \mathrm{m}^{2}, 300 \mathrm{~W} / \mathrm{m}^{2}, 350 \mathrm{~W} / \mathrm{m}^{2}, 400 \mathrm{~W} / \mathrm{m}^{2}$, $450 \mathrm{~W} / \mathrm{m}^{2}, 500 \mathrm{~W} / \mathrm{m}^{2}, 550 \mathrm{~W} / \mathrm{m}^{2}, 600 \mathrm{~W} / \mathrm{m}^{2}, 650 \mathrm{~W} / \mathrm{m}^{2}, 700 \mathrm{~W} / \mathrm{m}^{2}, 750 \mathrm{~W} / \mathrm{m}^{2}, 800 \mathrm{~W} / \mathrm{m}^{2}$, $850 \mathrm{~W} / \mathrm{m}^{2}, 900 \mathrm{~W} / \mathrm{m}^{2}, 950 \mathrm{~W} / \mathrm{m}^{2}$, and $1000 \mathrm{~W} / \mathrm{m}^{2}$. Second, the actual $V_{p v-m}^{\mathrm{G}}$ were compared with the 20 sets of $V_{p v-m}^{\mathrm{G}}$. Finally, the algorithm chose the closest set of $V_{p v-m}^{\mathrm{G}}$ to calculate the corresponding irradiance level (as shown in Table 3).

As shown in Figure 1a, the PV-M $P_{p v-m}-V_{p v-m}$ characteristic curves were analyzed, and as shown in Figure 1b, the PV-M $I_{p v-m}-V_{p v-m}$ characteristic curves were analyzed. Then, Microsoft Excel was used to draw the relationship among irradiance level, $P_{p v-m}$, and the temperature $(\mathrm{T}$ ) beelines (as shown in Figure 3). Figure 3 demonstrates the following eleven beelines that were drawn through the relationship among irradiance level, $P_{p v-m}$, and temperature $(\mathrm{T})$ : Beeline-A to Beeline-K present the characteristics at an irradiance level (G) from $100 \mathrm{~W} / \mathrm{m}^{2}$ to $1000 \mathrm{~W} / \mathrm{m}^{2}$ and the temperatures $10,15,20,25,30,35,40,45,50,55$, and $60{ }^{\circ} \mathrm{C}$, respectively. Beeline-A to Beeline-K were depicted PV-M output power $\left(P_{p v-m}\right)$ that the PV-M output maximum power $\left(P_{M P P}\right)$. In addition, to express the parameter $w$ 
equation, the mathematical model for the eleven beelines (as shown in Figure 3) could be approximated using the following equation:

$$
w=\mathrm{G}^{1.0256} \cdot P_{p v-m}^{-1}
$$

where the parameter $w$ is the compensation parameter that corresponds to the relationship of temperature. Figure 3 and Equation (4) show the relationship between parameter $w$ and temperature, as shown in Table 4.

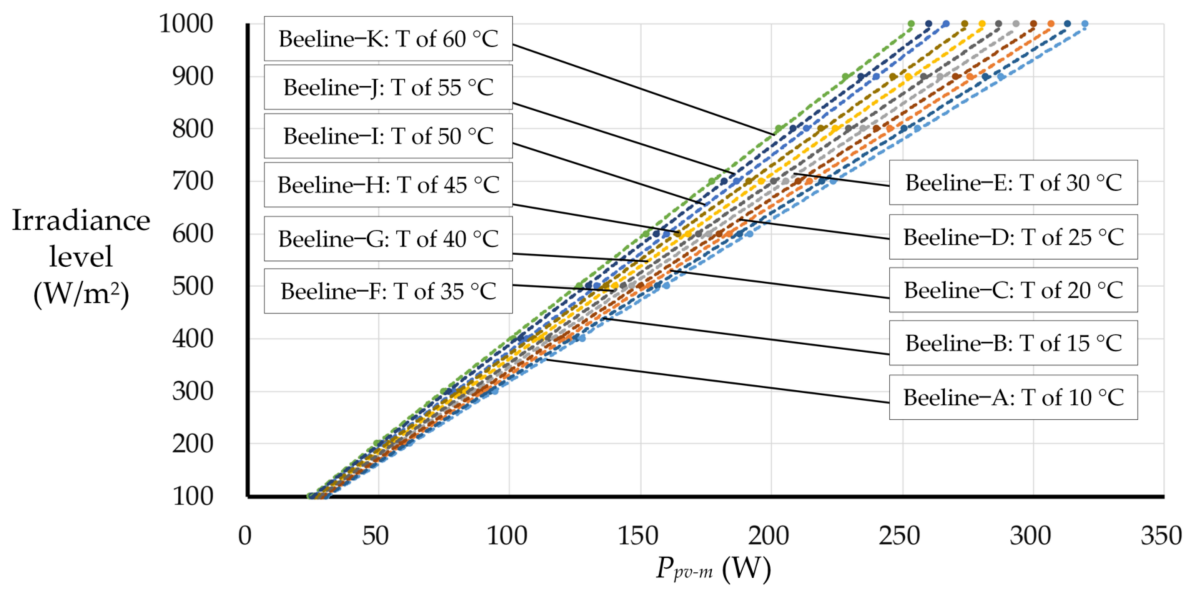

Figure 3. Relationship between irradiance level, $P_{p v-m}$, and temperature (T).

Table 4. Relationship between the parameter $w$ and temperature.

\begin{tabular}{cc}
\hline Temperature & Parameter $\boldsymbol{w}$ \\
\hline $10{ }^{\circ} \mathrm{C}$ & 3.5751 \\
\hline $15^{\circ} \mathrm{C}$ & 3.6474 \\
\hline $20^{\circ} \mathrm{C}$ & 3.7227 \\
\hline $25{ }^{\circ} \mathrm{C}$ & 3.8018 \\
\hline $30{ }^{\circ} \mathrm{C}$ & 3.8842 \\
\hline $35^{\circ} \mathrm{C}$ & 3.9715 \\
\hline $40^{\circ} \mathrm{C}$ & 4.0628 \\
\hline $45^{\circ} \mathrm{C}$ & 4.1599 \\
\hline $50{ }^{\circ} \mathrm{C}$ & 4.2618 \\
\hline $55^{\circ} \mathrm{C}$ & 4.3693 \\
\hline $60^{\circ} \mathrm{C}$ & 4.4826 \\
\hline
\end{tabular}

Table 4 displays the relationship between parameter $w$ and temperature. According to Equation (4) and Table 4, it was found that parameter $w$ could be obtained by the relationship between irradiance level and $P_{p v-m}$.

Under UIC, the proposed global-MPPT algorithm calculates the parameter $w$ of 3.5751 to 4.4826 from a temperature of $10{ }^{\circ} \mathrm{C}$ to $60{ }^{\circ} \mathrm{C}$ (as shown in Table 4 ). If the parameter $w$ was lower than 3.5751 or higher than 4.4826 , the PV-M was under a PSC.

In this research, the PV-M was connected with the boost converter, and the boost converter was connected to the load. Under ideal conditions, $P_{p v-m}=P_{0}$, and the relationship among PV-M impedance $\left(R_{p v-m}\right)$, load $\left(R_{o}\right)$, and duty cycle $(\mathrm{D})$ is expressed as follows:

$$
R_{o}=R_{p v-m} \cdot \frac{1}{(1-D)^{2}}
$$


PV-M impedance $\left(R_{p v-m}\right)$, load $\left(R_{o}\right)$, and duty cycle (D) can be obtained through Equation (6):

$$
\mathrm{D}=1-\sqrt{R_{p v-m} \cdot R_{o}^{-1}}
$$

Applying Equations (1) and (4) in Equation (6) yields the following equation for the relationship among PV-M output voltage $\left(V_{p v-m}\right)$, parameter $w$, duty cycle (D), irradiance level $(\mathrm{G})$, and load $\left(R_{o}\right)$ :

$$
\mathrm{D}=1-\sqrt{\frac{V_{p v-m}^{2} \cdot w}{R_{o} \cdot \mathrm{G}^{1.0256}}}
$$

Equation (7) considers load $\left(R_{o}\right)$, actual irradiance level (G), PV-M output voltage $\left(V_{p v-m}\right)$, and parameter $w$, where the parameter $w$ is the compensation parameter that corresponds to the relationship of temperature (as shown in Table 4). Thereby, D is the duty cycle of the global-MPPT.

The duty cycle can also be calculated by Equation (6). However, in this study the proposed global-MPPT algorithm analyzed the PV-M $I_{p v-m}-V_{p v-m}$ characteristic curves and PV-M $P_{p v-m}-V_{p v-m}$ characteristic curves that obtain the relationship between irradiance level and temperature, then judges the duty cycle of the MPP from irradiance level $(\mathrm{G})$, parameter $w$, load $\left(R_{o}\right)$, and PV-M output voltage $\left(V_{p v-m}\right)$ (as in Equation (7)). The proposed globalMPPT algorithm has the following advantages: first, the MPPT follows the actual irradiance level and temperature in accordance with the laws of nature. Second, Equations (1)-(7) and Tables 2-4 all have the compensating parameters for MPPT optimization. Finally, Equation (7) has many compensating parameters and is calculated carefully. Therefore, the proposed global-MPPT algorithm can provide a soft duty cycle of the MPPT to the power converter to reduce switching stress and enhance system performance.

In this study, according to Figures 1-3, Equations (1)-(7) and Tables 2-4 are the theoretical basis, where several parameters are compensated to ensure the reliability and accuracy of the MPPT. The proposed global-MPPT algorithm could immediately capture the MPP under a UIC and PSC. The proposed method has high performance that improves the shortcomings of the $\mathrm{P} \& \mathrm{O}$ algorithm: first, the algorithm has no disturbance characteristics; second, the actuating point would not be disturbed near the MPP; third, the algorithm can catch the MPP under a PSC; finally, this algorithm's convergence speed is high. In conclusion, this proposed global-MPPT algorithm is not a continuous iterative estimation, which reduces the MPPT tracking time. This algorithm also decreases the operating complexity of the microcontroller unit (MCU). Therefore, the proposed global-MPPT algorithm is better than the PSO algorithm.

Figure 4 displays the proposed global-MPPT algorithm flowchart. $V_{p v-m}$ is the PV-M output voltage; $I_{p v-m}$ is the PV-M output current; $V_{o}$ represents the boost converter output voltage; $I_{0}$ represents the boost converter output current; $x_{1}, y_{1}$, and $z_{1}$ are the parameters of Equation (3); parameter $w$ is from Equation (4); and D is the global-MPPT duty cycle of Equation (7). First, the proposed global-MPPT algorithm was used to measure $V_{p v-m}$, $I_{p v-m}, V_{o}$, and $I_{o}$ and calculate $P_{p v-m}$. Second, Equation (3) calculated 20 sets of $V_{p v-m}^{\mathrm{G}}$ of the irradiance levels $50 \mathrm{~W} / \mathrm{m}^{2}, 100 \mathrm{~W} / \mathrm{m}^{2}, 150 \mathrm{~W} / \mathrm{m}^{2}, 200 \mathrm{~W} / \mathrm{m}^{2}, 250 \mathrm{~W} / \mathrm{m}^{2}, 300 \mathrm{~W} / \mathrm{m}^{2}$, $350 \mathrm{~W} / \mathrm{m}^{2}, 400 \mathrm{~W} / \mathrm{m}^{2}, 450 \mathrm{~W} / \mathrm{m}^{2}, 500 \mathrm{~W} / \mathrm{m}^{2}, 550 \mathrm{~W} / \mathrm{m}^{2}, 600 \mathrm{~W} / \mathrm{m}^{2}, 650 \mathrm{~W} / \mathrm{m}^{2}, 700 \mathrm{~W} / \mathrm{m}^{2}$, $750 \mathrm{~W} / \mathrm{m}^{2}, 800 \mathrm{~W} / \mathrm{m}^{2}, 850 \mathrm{~W} / \mathrm{m}^{2}, 900 \mathrm{~W} / \mathrm{m}^{2}, 950 \mathrm{~W} / \mathrm{m}^{2}$, and $1000 \mathrm{~W} / \mathrm{m}^{2}$, and the actual $V_{p v-m}$ were compared with the 20 sets of $V_{p v-m}^{\mathrm{G}}$ to evaluate the actual irradiance level (G). Third, the proposed method determined parameter $w$ using Equation (4). Fourth, the proposed global-MPPT algorithm calculated $R_{0}$. Lastly, the global-MPPT duty cycle (D) was calculated by Equation (7), which includes the parameters irradiance level (G), load $\left(R_{o}\right)$, PV-M output voltage $\left(V_{p v-m}\right)$, and parameter $w$. In addition, if $I_{o}$ was less than zero, the duty cycle would $=0$. 


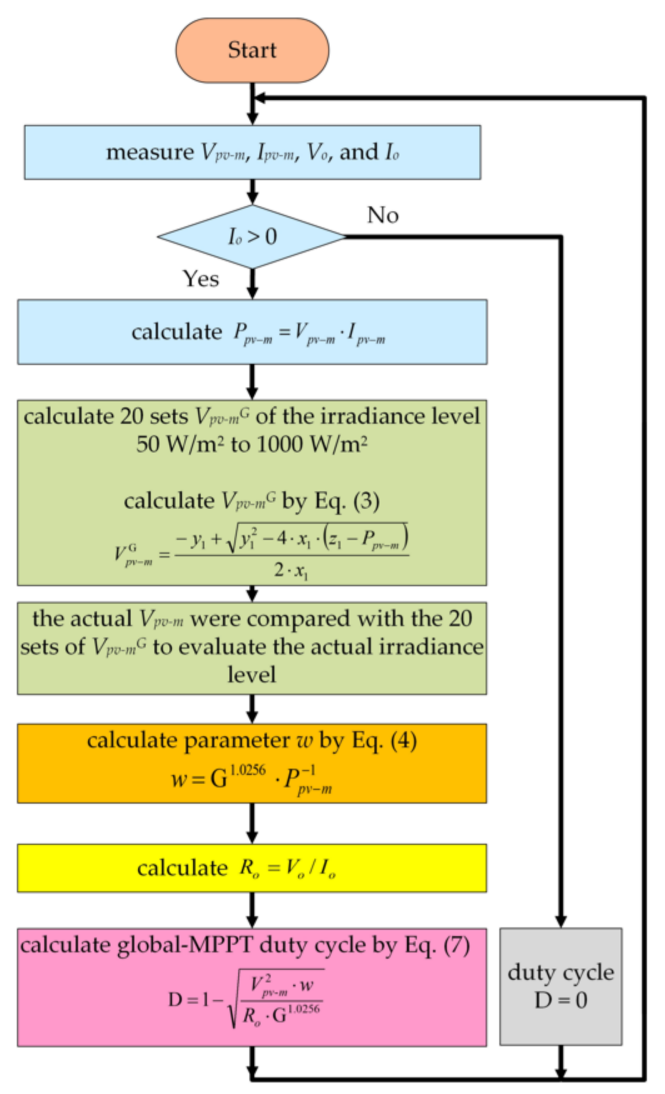

Figure 4. The proposed global-MPPT algorithm flowchart.

Figure 5 shows the diagram of the boost converter with the proposed global-MPPT algorithm, where the PV-M is connected to the boost converter for power electronics [38,39] and the proposed global-MPPT algorithm is embedded. The PV-M was a Chroma PV-M simulator (model number: $62020 \mathrm{H}-150 \mathrm{~S}$ ). When $\mathrm{G}=1000 \mathrm{~W} / \mathrm{m}^{2}$ and $\mathrm{T}=25^{\circ} \mathrm{C}, V_{o c}=44.95 \mathrm{~V}$, $I_{S C}=8.64 \mathrm{~A}, V_{M P P}=36.95 \mathrm{~V}, I_{M P P}=8.12 \mathrm{~A}$, and $P_{M P P}=300 \mathrm{~W}$ (as shown in Table 2). The boost converter elements include inductor $L_{1}\left(L_{1}\right.$ of $\left.0.6 \mathrm{mH}\right)$, capacitor $C_{1}\left(C_{1}\right.$ of $\left.470 \mu \mathrm{F}\right)$, diode $D_{1}$, and power MOSFET $\left(S_{1}\right)$. In this circuit, the $V_{p v-m}, I_{p v-m} V_{o}$, and $I_{o}$ signals were sent to the MPPT controller's MCU. The global-MPPT controller (Microchip, model number: 18F452) provides the PWM signal (frequency $=45 \mathrm{kHz}$ ) to drive the boost converter's power MOSFET $\left(S_{1}\right)$ so that the proposed system can search for the MPP and then catch the MPP.

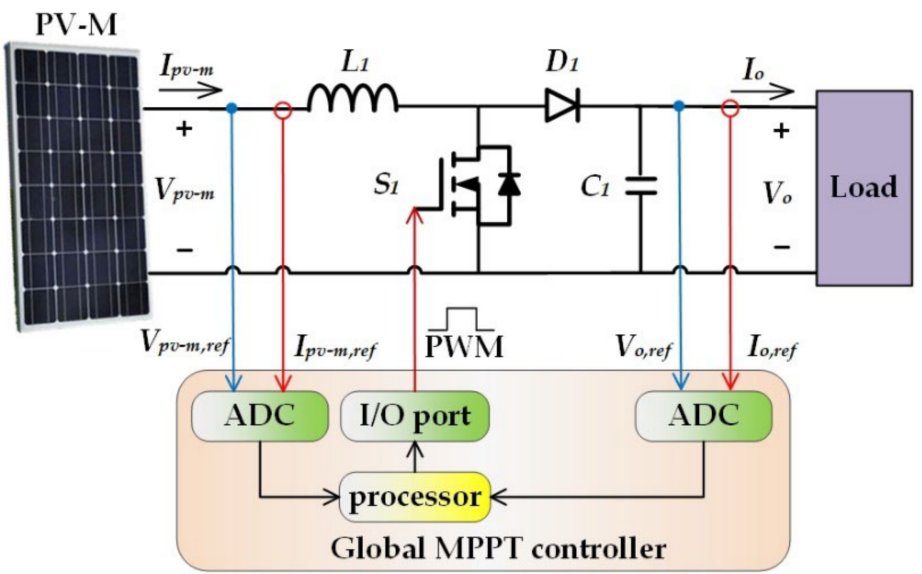

Figure 5. Diagram of the boost converter with the proposed global-MPPT algorithm. 


\section{Experimental Results}

Figure 6 presents the experimental PV-M simulator and the proposed global-MPPT algorithm prototype test setup. The PV-M simulator (Chroma, model number: $62020 \mathrm{H}-$ $150 \mathrm{~S}$ ) was set at the following specifications: $V_{o c}=44.95 \mathrm{~V}, I_{S C}=8.64 \mathrm{~A}, V_{M P P}=36.95 \mathrm{~V}$, $I_{M P P}=8.12 \mathrm{~A}$, and $P_{M P P}=300 \mathrm{~W}$ under the irradiance level $(\mathrm{G})=1000 \mathrm{~W} / \mathrm{m}^{2}$ and temperature $(\mathrm{T})=25^{\circ} \mathrm{C}$. In the test, the PV-M simulator was connected to the input of the boost converter, and the load was connected to the output of the boost converter. The MCU implemented the global-MPPT algorithm and provided the PWM signal to drive the boost converter and reach the MPP.

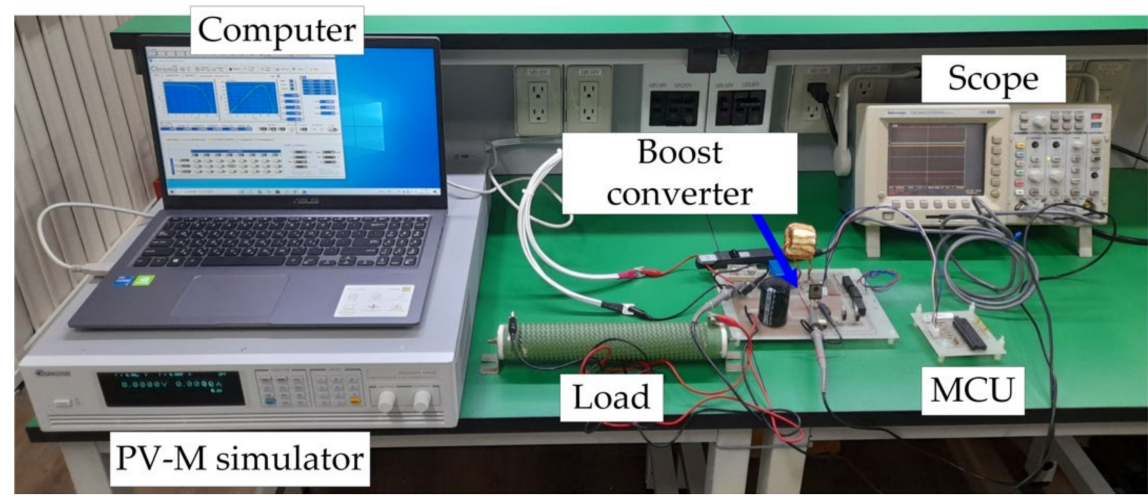

Figure 6. Experimental PV-M simulator and the proposed global-MPPT algorithm prototype test setup.

The MPPT efficiencies of the proposed global-MPPT algorithm, the PSO algorithm, and the $\mathrm{P} \& \mathrm{O}$ algorithm were tested experimentally under a UIC in which the irradiance level $(\mathrm{G})$ is $800 \mathrm{~W} / \mathrm{m}^{2}$ and $300 \mathrm{~W} / \mathrm{m}^{2}$, respectively. As shown in Figures 7-10 and Table 5, the results show that the efficiency of the proposed global-MPPT algorithm's MPPT was better than those of the PSO and P\&O algorithms.

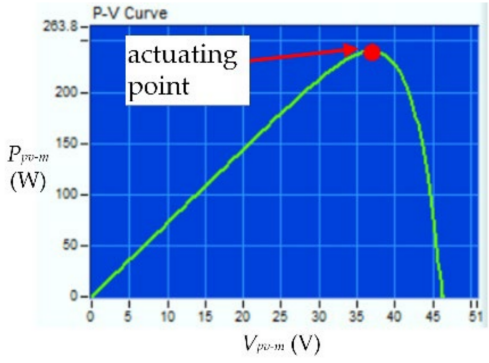

(a)

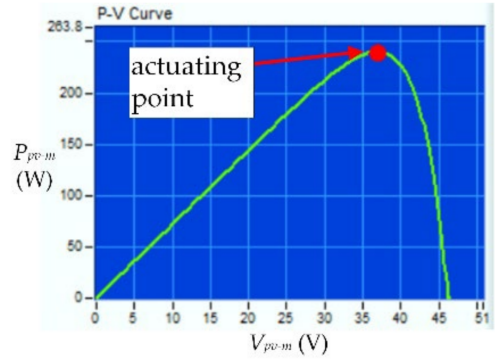

(b)

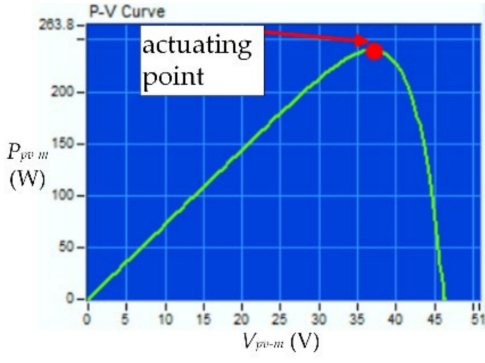

(c)

Figure 7. Experimental waveforms of PV-M $P_{p v-m}-V_{p v-m}$ characteristic curves under UIC in which $\mathrm{G}=800 \mathrm{~W} / \mathrm{m}^{2}$ and $\mathrm{T}=25^{\circ} \mathrm{C}:$ (a) proposed, (b) PSO, and (c) P\&O algorithms. 


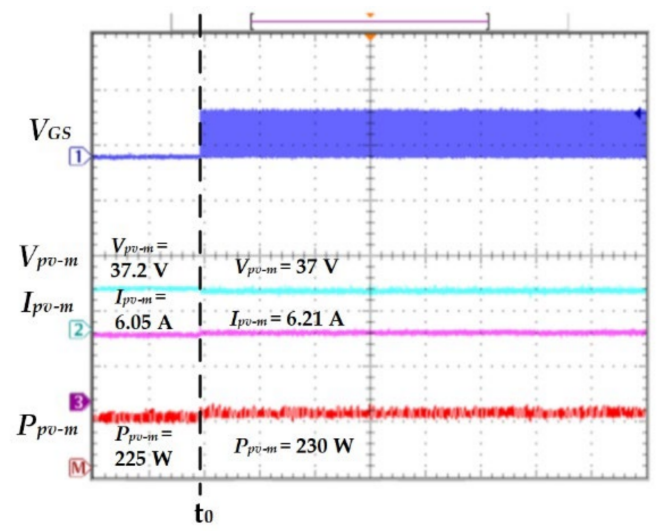

Figure 8. The proposed algorithm experimental waveforms of $V_{G S}, \mathrm{PV}-\mathrm{M} V_{p v-m}, \mathrm{PV}-\mathrm{M} I_{p v-m}$, and PV-M $P_{p v-m}$ under UIC in which $\mathrm{G}=800 \mathrm{~W} / \mathrm{m}^{2}$ and $\mathrm{T}=25^{\circ} \mathrm{C} .\left(20 \mathrm{~V} / \operatorname{div}\right.$ for $\mathrm{V}_{G S} ; 50 \mathrm{~V} / \operatorname{div}$ for $V_{p v-m}$; $5 \mathrm{~A} / \operatorname{div}$ for $I_{p v-m} ; 250 \mathrm{~W} / \operatorname{div}$ for $P_{p v-m} ;$ and $1 \mathrm{~s} / \operatorname{div}$ for Hor).

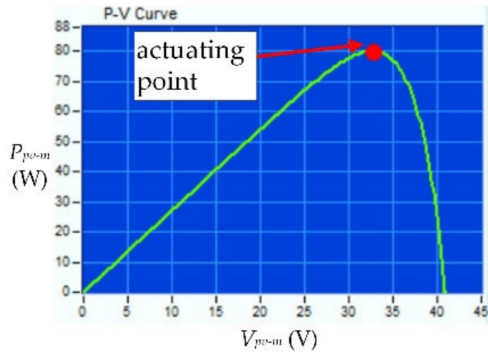

(a)

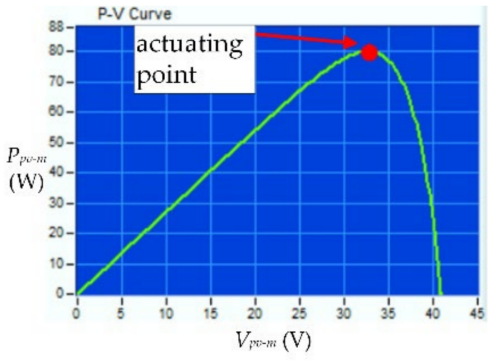

(b)

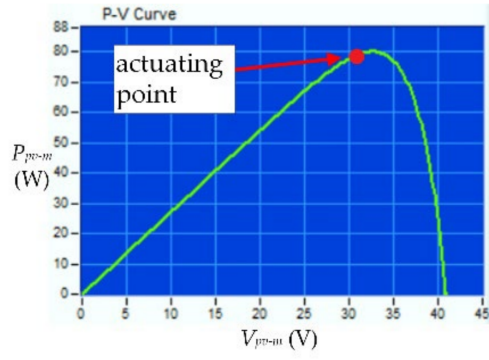

(c)

Figure 9. Experimental waveforms of PV-M $P_{p v-m}-V_{p v-m}$ characteristic curves under UIC in which $\mathrm{G}=300 \mathrm{~W} / \mathrm{m}^{2}$ and $\mathrm{T}=50{ }^{\circ} \mathrm{C}:$ (a) proposed, (b) P\&O, and (c) PSO algorithms.

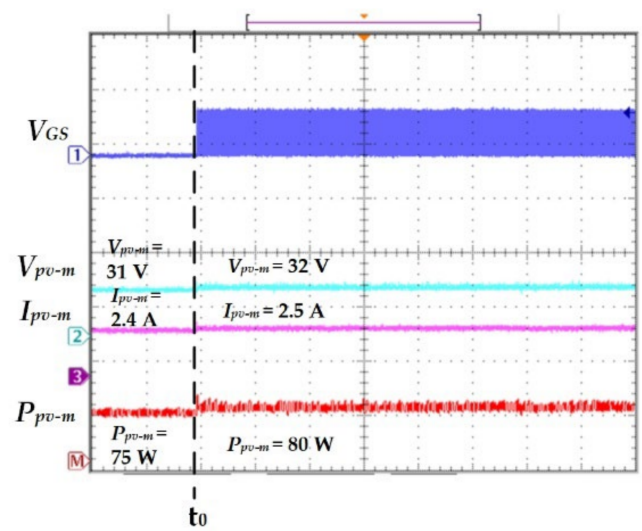

Figure 10. The proposed algorithm experimental waveforms of $V_{G S}, \mathrm{PV}-\mathrm{M} V_{p v-m}, \mathrm{PV}-\mathrm{M} I_{p v-m}$, and PV-M $P_{p v-m}$ under UIC in which $\mathrm{G}=300 \mathrm{~W} / \mathrm{m}^{2}$ and $\mathrm{T}=50{ }^{\circ} \mathrm{C} .\left(20 \mathrm{~V} / \mathrm{div}\right.$ for $\mathrm{V}_{G S} ; 30 \mathrm{~V} / \mathrm{div}$ for $V_{p v-m}$; $2.5 \mathrm{~A} / \operatorname{div}$ for $I_{p v-m} ; 80 \mathrm{~W} / \operatorname{div}$ for $P_{p v-m} ;$ and $1 \mathrm{~s} / \operatorname{div}$ for Hor).

Table 5. A comparison of three algorithms' MPPT efficiency under UIC.

\begin{tabular}{|c|c|c|c|c|c|c|}
\hline \multirow{2}{*}{ Algorithm } & \multicolumn{3}{|c|}{$\mathrm{G}=800 \mathrm{~W} / \mathrm{m}^{2}$ and $\mathrm{T}=25^{\circ} \mathrm{C}$} & \multicolumn{3}{|c|}{$\mathrm{G}=300 \mathrm{~W} / \mathrm{m}^{2}$ and $\mathrm{T}=50^{\circ} \mathrm{C}$} \\
\hline & $P_{M P P}(W)$ & $P_{p v-m}(\mathrm{~W})$ & Efficiency (\%) & $P_{M P P}(\mathrm{~W})$ & $P_{p v-m}(\mathrm{~W})$ & Efficiency (\%) \\
\hline Proposed & 240 & 239.8 & 99.9 & 80 & 79.8 & 99.8 \\
\hline PSO & 240 & 239.8 & 99.9 & 80 & 79.7 & 99.6 \\
\hline $\mathrm{P} \& \mathrm{O}$ & 240 & 239.5 & 99.8 & 80 & 78 & 97.5 \\
\hline
\end{tabular}


Figure 7 displays the test results for the proposed global-MPPT algorithm, PSO algorithm, and P\&O algorithm under a UIC in which irradiance level $(\mathrm{G})=800 \mathrm{~W} / \mathrm{m}^{2}$, and temperature $(\mathrm{T})=25^{\circ} \mathrm{C}$. Figure 7a illustrates the proposed global-MPPT algorithm experiment results. First, the proposed global-MPPT algorithm sensed $V_{p v-m}=37.2 \mathrm{~V}$, $P_{p v-m}=225 \mathrm{~W}$, and $R_{o}=6 \Omega$. Second, the proposed global-MPPT algorithm calculated $V_{p v-m}^{\mathrm{G}}=37 \mathrm{~V}$ by Equation (3), and the actual $V_{p v-m}$ was compared with the $V_{p v-m}{ }^{G}$ to evaluate the actual irradiance level $(\mathrm{G})=800 \mathrm{~W} / \mathrm{m}^{2}$ (as shown in Table 3), then calculated parameter $w=3.8$ by Equation (4), and the proposed global-MPPT algorithm estimated that the PV-M was under a UIC. Finally, it calculated the global-MPPT D $=0.5$ by Equation (7). When time $=\mathrm{t}_{0}$ (as shown in Figure 8), the proposed global-MPPT algorithm started, then the proposed global-MPPT algorithm reached the MPP, where the measured results are $V_{M P P}=37 \mathrm{~V}, I_{M P P}=6.21 \mathrm{~A}$, and $P_{M P P}=230 \mathrm{~W}$ (as in Figures 7a and 8). The proposed global-MPPT algorithm could be accurately and stably operated at the MPP with a system efficiency of $99.9 \%$.

Figure $7 \mathrm{~b}$ displays the $\mathrm{PSO}$ algorithm test results. This algorithm performed iterative calculations and could operate at the MPP with an MPPT efficiency of 99.9\%. Figure 7c displays the $\mathrm{P} \& \mathrm{O}$ algorithm test results. The algorithm detected the slope of the PV-M output power and PV-M output voltage and then operated the MPP. The algorithm's MPPT efficiency was $99.8 \%$ (as shown in Table 5).

Figure 9 illustrates the test results for the proposed global-MPPT algorithm, the PSO algorithm, and the P\&O algorithm under a UIC in which irradiance level $(\mathrm{G})=300 \mathrm{~W} / \mathrm{m}^{2}$ and temperature $(\mathrm{T})=50^{\circ} \mathrm{C}$. Figure $9 \mathrm{a}$ illustrates the proposed global-MPPT algorithm test results. First, the proposed global-MPPT algorithm measured $V_{p v-m}=31 \mathrm{~V}, P_{p v-m}=75 \mathrm{~W}$, and $R_{o}=13 \Omega$. Second, the proposed global-MPPT algorithm calculated $V_{p v-m}{ }^{\mathrm{G}}=32 \mathrm{~V}$ using Equation (3), and the actual $V_{p v-m}$ was compared with the $V_{p v-m}^{\mathrm{G}}$ to evaluate the actual irradiance level $(\mathrm{G})=300 \mathrm{~W} / \mathrm{m}^{2}$ (as shown in Table 3), then calculated parameter $w=4.3$ using Equation (4), and the proposed global-MPPT algorithm estimated that the PV-M was under a UIC. Finally, it calculated global-MPPT D $=0.05$ using Equation (7). When time $=\mathrm{t}_{0}$ (as shown in Figure 10), the proposed global-MPPT algorithm started, then the proposed global-MPPT algorithm reached the MPP, where the measured results were $V_{M P P}=32 \mathrm{~V}$, $I_{M P P}=2.5 \mathrm{~A}$, and $P_{M P P}=80 \mathrm{~W}$ (as in Figures $9 \mathrm{a}$ and 10). The proposed global-MPPT algorithm could be accurately and stably operated at the MPP, with a system efficiency of $99.8 \%$.

Figure $9 \mathrm{~b}$ displays the PSO algorithm test results. This algorithm was an iterative calculation, and it could operate at the MPP with an MPPT efficiency of 99.6\%. Figure 9c displays the $\mathrm{P} \& \mathrm{O}$ algorithm test results. The algorithm detected the slope of the PV-M output power and the PV-M output voltage and then operated at the MPP. As the algorithm actuating point vibrated, the MPPT efficiency was $97.5 \%$ (as shown in Table 5).

Table 5 shows the comparison among the three algorithms' MPPT efficiencies under a UIC. The proposed global-MPPT algorithm had MPPT efficiency of $99.9 \%$ and $99.8 \%$ under $800 \mathrm{~W} / \mathrm{m}^{2}$ and $300 \mathrm{~W} / \mathrm{m}^{2}$, respectively. In addition, the proposed global-MPPT algorithm's efficiency was higher than those of the PSO and P\&O algorithms. Therefore, this experiment proved that the proposed global-MPPT algorithm had higher efficiency and was suitable for different irradiance levels and temperatures.

The MPPT efficiencies of the proposed global-MPPT algorithm, the PSO algorithm, and the $\mathrm{P} \& \mathrm{O}$ algorithm were tested experimentally under a PSC. Figure 11 displays the diagram of the PV-M's solar cell array for shadow simulation through single PV-M simulator software in this study. The structure of the PV-M's solar cell array was $12 \times 5$. In this test, under a PSC in which irradiance level $(\mathrm{G})=900 \mathrm{~W} / \mathrm{m}^{2}$, temperature $(\mathrm{T})=25^{\circ} \mathrm{C}$, twenty-four solar cells were shaded in the PV-M (represented by the black square shown in Figure 11). Then, the PV-M's characteristics were measured, where $V_{M P P}=29.9 \mathrm{~V}$, $I_{M P P}=4.23 \mathrm{~A}$, and $P_{M P P}=126.6 \mathrm{~W}$. These test results show that the MPPT efficiency of the proposed global-MPPT algorithm was better than those of the PSO and P\&O algorithms, as shown in Figures 12 and 13, and Table 6. 


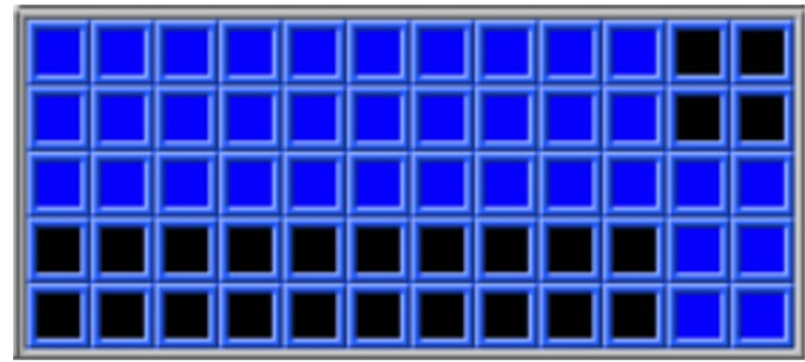

Figure 11. Diagram of the PV-M's solar cell array for shadow simulation through a single PV-M simulator in which $\mathrm{G}=900 \mathrm{~W} / \mathrm{m}^{2}$ and $\mathrm{T}=25^{\circ} \mathrm{C}$.

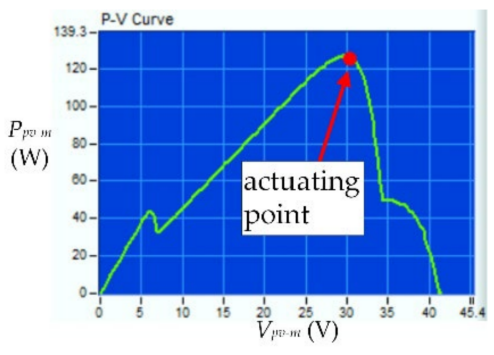

(a)

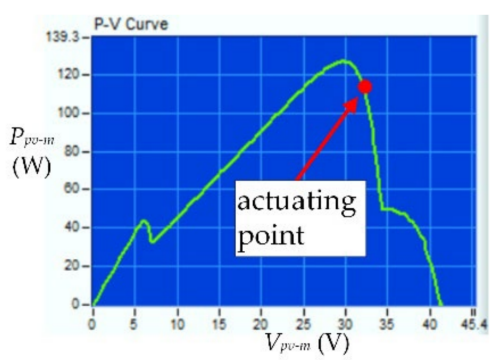

(b)

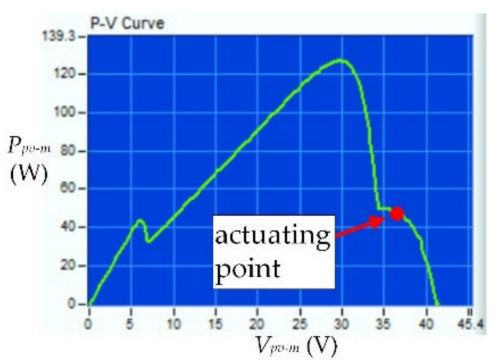

(c)

Figure 12. Experimental waveforms of PV-M $P_{p v-m}-V_{p v-m}$ characteristic curves under PSC in which $\mathrm{G}=900 \mathrm{~W} / \mathrm{m}^{2}$ and $\mathrm{T}=25^{\circ} \mathrm{C}:$ (a) proposed, (b) P\&O, and (c) PSO algorithms.

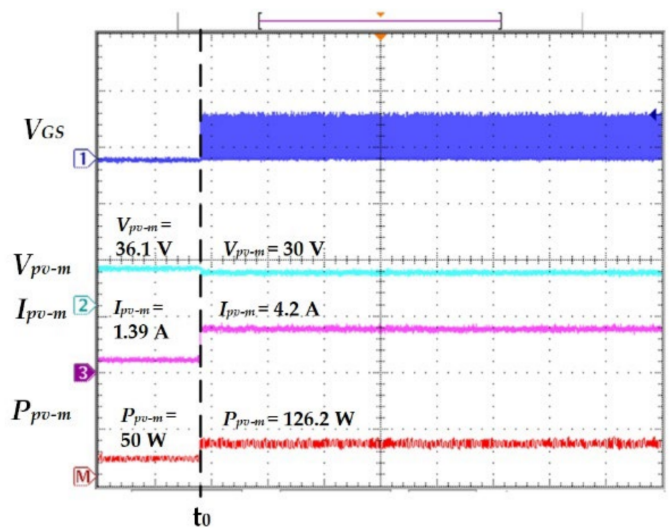

Figure 13. The proposed algorithm experimental waveforms of $V_{G S}, \mathrm{PV}-\mathrm{M} V_{p v-m}, \mathrm{PV}-\mathrm{M} I_{p v-m}$, and PV-M $P_{p v-m}$ under PSC in which $\mathrm{G}=900 \mathrm{~W} / \mathrm{m}^{2}$ and $\mathrm{T}=25^{\circ} \mathrm{C}$. $\left(20 \mathrm{~V} / \operatorname{div}\right.$ for $\mathrm{V}_{G S} ; 50 \mathrm{~V} / \operatorname{div}$ for $V_{p v-m}$; $5 \mathrm{~A} / \operatorname{div}$ for $I_{p v-m} ; 250 \mathrm{~W} / \operatorname{div}$ for $P_{p v-m} ;$ and $1 \mathrm{~s} / \operatorname{div}$ for Hor).

Table 6. A comparison among three algorithms' MPPT efficiency under PSC.

\begin{tabular}{|c|c|c|c|c|c|c|}
\hline \multirow{2}{*}{ Algorithm } & \multicolumn{3}{|c|}{$\mathrm{G}=900 \mathrm{~W} / \mathrm{m}^{2}$ and $\mathrm{T}=25^{\circ} \mathrm{C}$} & \multicolumn{3}{|c|}{$\mathrm{G}=600 \mathrm{~W} / \mathrm{m}^{2}$ and $\mathrm{T}=40^{\circ} \mathrm{C}$} \\
\hline & $P_{M P P}(\mathrm{~W})$ & $P_{p v-m}(\mathrm{~W})$ & Efficiency (\%) & $P_{M P P}(\mathrm{~W})$ & $P_{p v-m}(\mathrm{~W})$ & Efficiency (\%) \\
\hline Proposed & 126.6 & 126.2 & 99.7 & 100 & 99.5 & 99.5 \\
\hline PSO & 126.6 & 117.5 & 92.8 & 100 & 95.1 & 95.1 \\
\hline $\mathrm{P} \& \mathrm{O}$ & 126.6 & 49.1 & 38.8 & 100 & 28.5 & 28.5 \\
\hline
\end{tabular}

Figure 12 illustrates test results for the proposed global-MPPT algorithm, PSO algorithm, and P\&O algorithm under a PSC in which irradiance level $(\mathrm{G})=900 \mathrm{~W} / \mathrm{m}^{2}$ and temperature $(\mathrm{T})=25^{\circ} \mathrm{C}$. Figure $12 \mathrm{a}$ illustrates the test results for the proposed globalMPPT algorithm. First, the proposed global-MPPT algorithm measured $V_{p v-m}=36.1 \mathrm{~V}$, $P_{p v-m}=50 \mathrm{~W}$, and $R_{o}=28 \Omega$. Second, the proposed global-MPPT algorithm calculated 
$V_{p v-m}^{\mathrm{G}}=36.7 \mathrm{~V}$ using Equation (3), and the actual $V_{p v-m}$ was compared with the $V_{p v-m}^{\mathrm{G}}$ to evaluate the actual irradiance level $(G)=900 \mathrm{~W} / \mathrm{m}^{2}$ (as shown in Table 3), then calculated parameter $w=21.2$ using Equation (4), and the proposed global-MPPT algorithm estimated that the PV-M was under a PSC. Finally, it calculated the global-MPPT D $=0.05$ using Equation (7). When time $=t_{0}$ (as shown in Figure 13), the proposed global-MPPT algorithm starts, the proposed global-MPPT algorithm reached the global MPP, and then measured results that $V_{M P P}=30 \mathrm{~V}, I_{M P P}=4.2 \mathrm{~A}$, and $P_{M P P}=126.2 \mathrm{~W}$ (as in Figures 12a and 13). The proposed global-MPPT algorithm considered the irradiance level and load, etc. Therefore, under a PSC, the proposed global-MPPT algorithm could be accurately and stably operated at the global MPP, with a system efficiency of $99.7 \%$.

Figure $12 \mathrm{~b}$ displays the PSO algorithm test results. This algorithm was an iterative calculation and searched for the global MPP. However, the algorithm's execution time was longer than that for the proposed global-MPPT algorithm and it could not capture the global MPP in time, therefore the MPPT efficiency was $92.8 \%$. Figure $12 \mathrm{c}$ displays the P\&O algorithm test results. The algorithm detected the slope of the PV-M output power and the PV-M output voltage, and then searched for the global MPP. However, the algorithm became trapped in the local MPP. Therefore, the MPPT efficiency was $38.8 \%$ (as shown in Table 6).

Figure 14 shows that the combination of the PV-M's solar cell array was $12 \times 5$. In this test, under a PSC in which irradiance level $(\mathrm{G})=600 \mathrm{~W} / \mathrm{m}^{2}$, temperature $(\mathrm{T})=40{ }^{\circ} \mathrm{C}$, and twenty solar cells were shaded in the PV-M (represented by the black squares shown in Figure 14), PV-M $V_{M P P}=19.6 \mathrm{~V}, I_{M P P}=5.1 \mathrm{~A}$, and $P_{M P P}=100 \mathrm{~W}$. The test results show that the MPPT efficiency of the proposed global-MPPT algorithm was better than those of the PSO and P\&O algorithms, as shown in Figures 15 and 16, and Table 6.

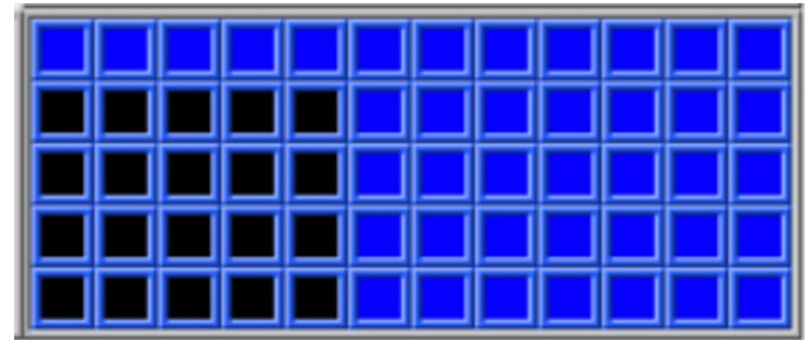

Figure 14. Diagram of the PV-M's solar cell array for shadow simulation through a single PV-M simulator in which $\mathrm{G}=600 \mathrm{~W} / \mathrm{m}^{2}$ and $\mathrm{T}=40^{\circ} \mathrm{C}$.

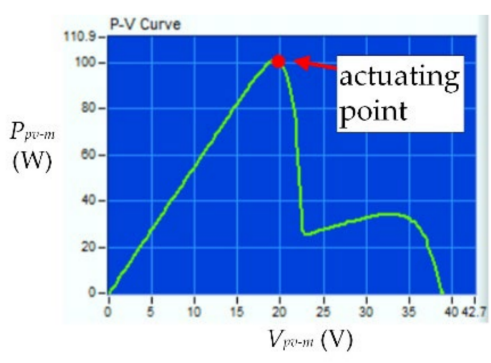

(a)

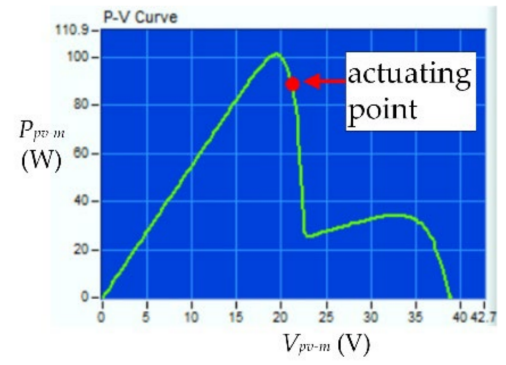

(b)

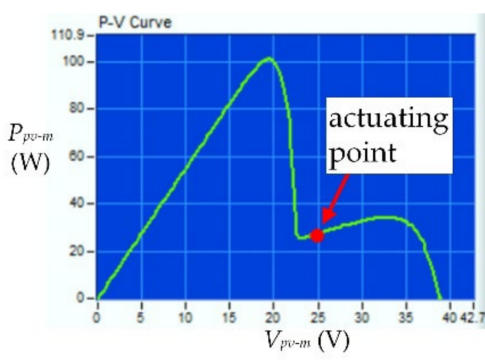

(c)

Figure 15. Experimental waveforms of PV-M $P_{p v-m}-V_{p v-m}$ characteristic curves under PSC in which $\mathrm{G}=600 \mathrm{~W} / \mathrm{m}^{2}$ and $\mathrm{T}=40{ }^{\circ} \mathrm{C}:(\mathbf{a})$ proposed, (b) P\&O, and (c) PSO algorithms. 


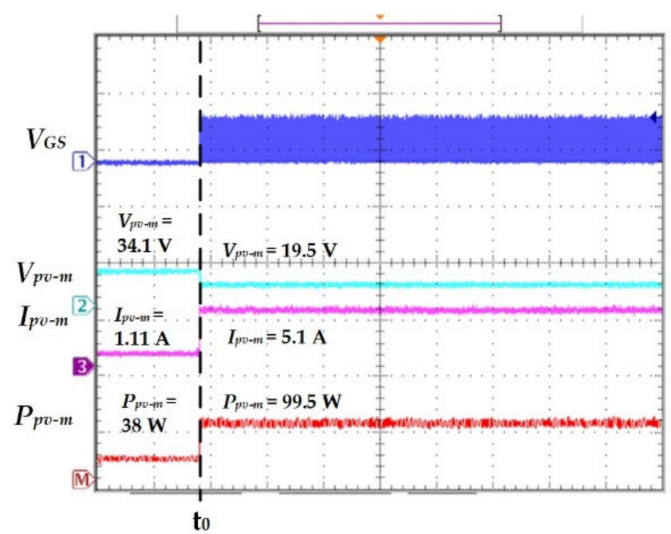

Figure 16. The proposed algorithm experimental waveforms of $V_{G S}, \mathrm{PV}-\mathrm{M} V_{p v-m}, \mathrm{PV}-\mathrm{M} I_{p v-m}$, and PV-M $P_{p v-m}$ under PSC in which $\mathrm{G}=600 \mathrm{~W} / \mathrm{m}^{2}$ and $\mathrm{T}=40{ }^{\circ} \mathrm{C}$. $\left(20 \mathrm{~V} / \operatorname{div}\right.$ for $\mathrm{V}_{G S} ; 50 \mathrm{~V} / \operatorname{div}$ for $V_{p v-m}$; $5 \mathrm{~A} / \operatorname{div}$ for $I_{p v-m} ; 100 \mathrm{~W} / \operatorname{div}$ for $P_{p v-m} ;$ and $1 \mathrm{~s} / \operatorname{div}$ for Hor).

Figure 15 shows the test results for the proposed global-MPPT algorithm, the PSO algorithm, and the P\&O algorithm, under a PSC in which irradiance level $(G)=600 \mathrm{~W} / \mathrm{m}^{2}$ and temperature $(\mathrm{T})=40^{\circ} \mathrm{C}$. Figure 15a illustrates the proposed global-MPPT algorithm test results. First, the proposed global-MPPT algorithm sensed $V_{p v-m}=34.1 \mathrm{~V}, P_{p v-m}=38 \mathrm{~W}$, and $R_{o}=30 \Omega$. Second, the proposed global-MPPT algorithm calculated $V_{p v-m}^{\mathrm{G}}=34.3 \mathrm{~V}$ using Equation (3), and the actual $V_{p v-m}$ was compared with the $V_{p v-m}^{\mathrm{G}}$ to evaluate the actual irradiance level $(G)=600 \mathrm{~W} / \mathrm{m}^{2}$ (as shown in Table 3), then calculated parameter $w=18.1$ using Equation (4), and the proposed global-MPPT algorithm estimated that the PV-M was under a PSC. Finally, it calculated the global-MPPT D $=0.03$ using Equation (7). When time $=\mathrm{t}_{0}$ (as shown in Figure 16) the proposed global-MPPT algorithm starts up, then the proposed global-MPPT algorithm reached the global MPP, and measured results that $V_{M P P}=19.5 \mathrm{~V}, I_{M P P}=5.1 \mathrm{~A}$, and $P_{M P P}=99.5 \mathrm{~W}$ (as in Figures 15a and 16). The proposed global-MPPT algorithm considered the irradiance level and the load, etc. Therefore, the proposed global-MPPT algorithm under a PSC could be accurately and stably operated at the global MPP (as shown in Figure 12a), with a system efficiency of $99.5 \%$.

Figure $15 \mathrm{~b}$ displays the PSO algorithm test results. This algorithm was an iterative calculation and searched for the global MPP. However, the algorithm's execution time was longer than that of the proposed global-MPPT algorithm, and it could not capture the global MPP in time (as shown in Figure 12b). Therefore, the MPPT efficiency was 95.1\%. Figure $15 \mathrm{c}$ displays the $\mathrm{P} \& \mathrm{O}$ algorithm test results. The algorithm detected the slope of the PV-M output power and the PV-M output voltage, and then searched for the global MPP. However, the algorithm became trapped in the local peak power point (as shown in Figure 12c). Therefore, the MPPT efficiency was $28.5 \%$ (as shown in Table 6).

Table 6 shows a comparison among the three algorithms' MPPT efficiency under a PSC. The proposed global-MPPT algorithm's MPPT efficiency was $99.7 \%$ and $99.5 \%$ under $900 \mathrm{~W} / \mathrm{m}^{2}$ and $600 \mathrm{~W} / \mathrm{m}^{2}$, respectively. In addition, the proposed global-MPPT algorithm's efficiency was better than those of the PSO and $\mathrm{P} \& \mathrm{O}$ algorithms. Therefore, this experiment proved that the proposed global-MPPT algorithm had high efficiency and was suitable for a PSC.

\section{Conclusions}

In this study, the proposed global-MPPT algorithm was proposed to analyze the irradiance level, the output voltage, and the output power of the PV-M. In the proposed algorithm, the important parameter $w$ is determined by the PV-M output power and irradiance level, which is also the compensation parameter that corresponds to the relationship of temperature. The proposed global-MPPT algorithm was developed to predict the best duty cycle for the global-MPPT based on the irradiance level, parameter $w$, PV-M output voltage, and load so that the PV-M can achieve the MPP quickly and accurately. The test 
results verified that under a UIC, the proposed global-MPPT algorithm's MPPT efficiency was $99.9 \%$ and $99.8 \%$ under $800 \mathrm{~W} / \mathrm{m}^{2}$ and $300 \mathrm{~W} / \mathrm{m}^{2}$, respectively. In addition, under a PSC, the proposed global-MPPT algorithm's MPPT efficiency was $99.7 \%$ and $99.5 \%$ under $900 \mathrm{~W} / \mathrm{m}^{2}$ and $600 \mathrm{~W} / \mathrm{m}^{2}$, respectively. In summary, under a UIC and PSC, the proposed global-MPPT algorithm's MPPT performed better than the PSO and P\&O algorithms.

The proposed global-MPPT algorithm considered the change in the irradiance level, parameter $w$, PV-M output voltage, and load. Therefore, under a UIC and PSC, the proposed global-MPPT algorithm could quickly and accurately capture the MPP. The proposed system of this study did not require a complex power electronic circuit architecture and complex calculation. Further, it could accurately reach the MPP and greatly reduce the design cost.

In future work, the proposed global-MPPT algorithm uses two voltage sensors and two current sensors that increase manufacturing costs. In the future, the research can focus on reducing sensors with new MPPT algorithms to reach lower costs and complexity. The proposed global-MPPT algorithm can be applied to rooftop solar power systems, which are often shaded. The proposed global-MPPT algorithm could improve the power generation efficiency of these solar power systems. In addition, future studies can develop a novel power electronic converter that solves the shadowing problem. Combining this novel power electronic converter with the proposed global-MPPT algorithm could take PSC research on PV-Ms to the next level.

Author Contributions: S.-D.L., C.-H.L., H.-D.L. and C.-M.H. conceived of the presented idea design and experiment; Y.-L.L. and L.-Y.H. carried out testing and verification; P.-C.L. and G.-J.G. wrote the original draft of this article; L.-Y.H., Y.-L.L. and H.-D.L. reviewed and edited this article; H.-D.L. supervised the findings of this work. All authors provided critical feedback and helped shape the research, analysis, and manuscript. All authors have read and agreed to the published version of the manuscript.

Funding: This research was funded by the financial support of the Ministry of Science and Technology of Taiwan, under contract number: MOST 110-2221-E-167-025, and the National Taiwan Normal University Subsidy Policy to Enhance Academic Research Projects.

Institutional Review Board Statement: Not applicable.

Informed Consent Statement: Not applicable.

Data Availability Statement: Not applicable.

Conflicts of Interest: The authors declare no conflict of interest.

\section{References}

1. Shariff, S.M.; Alam, M.S.; Ahmad, F.; Rafat, Y.; Asghar, M.S.J.; Khan, S. System Design and Realization of a Solar-Powered Electric Vehicle Charging Station. IEEE Syst. J. 2020, 14, 2748-2758. [CrossRef]

2. Teshima, Y.; Hirakoso, N.; Shigematsu, Y.; Hirama, Y.; Kawabata, H. Optimal Driving Strategy for Solar Electric Vehicle. IEEJ J. Ind. Appl. 2021, 10, 303-309. [CrossRef]

3. Wang, Y.; Zhang, B.; Yang, Y.; Wen, H.; Zhang, Y.; Chen, X. A new optimized control system architecture for solar photovoltaic energy storage application. IEICE Electron. Express 2021, 18, 1-6. [CrossRef]

4. Chiu, H.-J.; Lo, Y.-K.; Yao, C.-J.; Cheng, S.-J. Design and Implementation of a Photovoltaic High-Intensity-Discharge Street Lighting System. IEEE Trans. Power Electron. 2011, 26, 3464-3471. [CrossRef]

5. Amin, Z.M.; Maswood, A.I.; Hawlader, M.N.A.; Ammar, E.A.A.; Orfi, J.; Ansary, H.A.A. Desalination With a Solar-Assisted Heat Pump: An Economic Optimization. IEEE Syst. J. 2013, 7, 732-741. [CrossRef]

6. Joshi, R.S.; Gupta, S.B. Diagnostic of Neutralization Current for Arcs on Satellite Solar Panel Coupons. IEEE Trans. Plasma Sci. 2015, 43, 3000-3005. [CrossRef]

7. Khezri, R.; Mahmoudi, A.; Haque, M.H. Optimal Capacity of Solar PV and Battery Storage for Australian Grid-Connected Households. IEEE Trans. Ind. Appl. 2020, 56, 5319-5329. [CrossRef]

8. Nasu, S.; Tajima, S.; Sugai, Y. Method of Priority Order for Simultaneous Solar-Derived Power Usage at a Solar-Powered House and Neighborhood. Int. J. Autom. Technol. 2020, 14, 1013-1024. [CrossRef]

9. Boottaraja, P.; Phuangpornpitak, N. Performance Analysis of $325 \mathrm{~kW}$ Solar PV Rooftop System Using PVsyst Program. Int. J. Environ. Rural Dev. 2021, 10, 40-45. [CrossRef] 
10. Xiao, S.; Ou, Z.; Peng, J.; Zhang, Y.; Zhang, X. Single-Phase Photovoltaic Grid-Connected Inverter Based on Fuzzy Neural Network. J. Adv. Comput. Intell. Intell. Inform. 2021, 25, 310-316. [CrossRef]

11. Alfughi, Z.; Rahnamayan, S.; Yilbas, B. Multi-Objective Solar Farm Design Based on Parabolic Collectors. J. Adv. Comput. Intell. Intell. Inform. 2018, 22, 256-270. [CrossRef]

12. Kawasaki, K.; Nakakura, M.; Matsubara, K. Conjugate simulation of solar honeycomb receiver for high temperature heat absorption at constant incident heat flux. J. Therm. Sci. Technol. 2020, 15, 1-12. [CrossRef]

13. Gajic, A.; Stevanovic, V.; Pejovic, S. Pumped-Hydro Storages are Balancing Electric Energy Production of Wind and Solar Reducing Average Costs and Pollution. Int. J. Fluid Mach. Syst. 2019, 12, 47-55. [CrossRef]

14. Aratame, K. Basic Analysis of Supplying Characteristics of Photovoltaic and Wind Generating Electricity. IEEJ Trans. Power Energy 2021, 141, 551-558. [CrossRef]

15. Bhunia, M.; Subudhi, B.; Ray, P.K. Design and Real-Time Implementation of Cascaded Model Reference Adaptive Controllers for a Three-Phase Grid-Connected PV System. IEEE J. Photovolt. 2021, 11, 1319-1331. [CrossRef]

16. Abouadane, H.; Fakkar, A.; Sera, D.; Lashab, A.; Spataru, S.; Kerekes, T. Multiple-Power-Sample Based P\&O MPPT for FastChanging Irradiance Conditions for a Simple Implementation. IEEE J. Photovolt. 2020, 10, 1481-1488. [CrossRef]

17. Jayawardana, I.D.G.; Ho, C.N.M.; Pokharel, M.; Valderrama, G.E. A Fast-Dynamic Control Scheme for a Power-Electronics-Based PV Emulator. IEEE J. Photovolt. 2021, 11, 485-495. [CrossRef]

18. Kumar, N.; Singh, B.; Wang, J.; Panigrahi, B.K. A Framework of L-HC and AM-MKF for Accurate Harmonic Supportive Control Schemes. IEEE Trans. Circuits Syst. I Regul. Pap. 2020, 67, 5246-5256. [CrossRef]

19. Ji, B.; Hata, K.; Imura, T.; Hori, Y.; Honda, S.; Shimada, S.; Kawasaki, O. A Novel Particle Jump Particle Swarm Optimization Method for PV MPPT Control under Partial Shading Conditions. IEEJ J. Ind. Appl. 2020, 9, 435-443. [CrossRef]

20. Ji, B.; Hata, K.; Imura, T.; Hori, Y.; Shimada, S.; Kawasaki, O. PV MPPT Control under Partial Shading Conditions with a Particle Replacement Gaussian Particle Swarm Optimization Method. IEEJ J. Ind. Appl. 2020, 9, 418-427. [CrossRef]

21. Liu, H.-D.; Lin, C.-H.; Lu, S.-D. A novel MPPT algorithm considering solar photovoltaic modules and load characteristics for a single stage standalone solar photovoltaic system. IEICE Electron. Express 2020, 17, 1-6. [CrossRef]

22. Liu, H.-D.; Lu, S.-D. A high-performance MPPT algorithm combining advanced three-point weight comparison and temporary stopped running strategy for PV systems. IEICE Electron. Express 2019, 16, 1-6. [CrossRef]

23. Saito, H.; Aoki, D.; Tobe, T.; Magaino, S. Development of a New Maximum Power Point Tracking Method for Power Conversion Efficiency Measurement of Metastable Perovskite Solar Cells. Electrochemistry 2020, 88, 218-223. [CrossRef]

24. Castaño, C.G.; Restrepo, C.; Kouro, S.; Rodriguez, J. MPPT Algorithm Based on Artificial Bee Colony for PV System. IEEE Access 2021, 9, 43121-43133. [CrossRef]

25. Avila, L.; Paula, M.D.; Carlucho, I.; Reinoso, C.S. MPPT for PV systems using deep reinforcement learning algorithms. IEEE Lat. Am. Trans. 2019, 17, 2020-2027. [CrossRef]

26. Subudhi, B.; Pradhan, R. A New Adaptive Maximum Power Point Controller for a Photovoltaic System. IEEE Trans. Sustain. Energy 2019, 10, 1625-1632. [CrossRef]

27. Singh, N.; Gupta, K.K.; Jain, S.K.; Dewangan, N.K.; Bhatnagar, P. A Flying Squirrel Search Optimization for MPPT Under Partial Shaded Photovoltaic System. IEEE J. Emerg. Sel. Top. Power Electron. 2019, 9, 4963-4978. [CrossRef]

28. Chang, M.-C.; Liu, S.-I. An Indoor Photovoltaic Energy Harvester Using Time-Based MPPT and On-Chip Photovoltaic Cell. IEEE Trans. Circuits Syst. II Express Briefs 2020, 67, 2432-2436. [CrossRef]

29. Zhang, L.; Yu, S.S.; Fernando, T.; Iu, H.H.-C.; Wong, K.P. An online maximum power point capturing technique for high-efficiency power generation of solar photovoltaic systems. J. Mod. Power Syst. Clean Energy 2019, 7, 357-368. [CrossRef]

30. Pradhan, C.; Senapati, M.K.; Malla, S.G.; Nayak, P.K.; Gjengedal, T. Coordinated Power Management and Control of Standalone PV-Hybrid System With Modified IWO-Based MPPT. IEEE Syst. J. 2021, 15, 3585-3596. [CrossRef]

31. Barth, C.; Podgurski, R.C.N.P. Dithering Digital Ripple Correlation Control for Photovoltaic Maximum Power Point Tracking IEEE Trans. Power Electron. 2015, 30, 4548-4559. [CrossRef]

32. Sutikno, T.; Subrata, A.C.; Elkhateb, A. Evaluation of Fuzzy Membership Function Effects for Maximum Power Point Tracking Technique of Photovoltaic System. IEEE Access 2021, 9, 109157-109165. [CrossRef]

33. Allahabadi, S.; Eini, H.I.; Farhangi, S. Fast Artificial Neural Network Based Method for Estimation of the Global Maximum Power Point in Photovoltaic Systems. IEEE Trans. Ind. Electron. 2022, 69, 5879-5888. [CrossRef]

34. Kumar, N.; Hussain, I.; Singh, B.; Panigrahi, B.K. Maximum Power Peak Detection of Partially Shaded PV Panel by Using Intelligent Monkey King Evolution Algorithm. IEEE Trans. Ind. Appl. 2017, 53, 5734-5743. [CrossRef]

35. Obukhov, S.; Ibrahim, A.; Diab, A.A.Z.; Sumaiti, A.S.A.; Aboelsaud, R. Optimal Performance of Dynamic Particle Swarm Optimization Based Maximum Power Trackers for Stand-Alone PV System Under Partial Shading Conditions. IEEE Access 2020, 8, 20770-20785. [CrossRef]

36. Tian, A.-Q.; Chu, S.-C.; Pan, J.-S.; Liang, Y. A Novel Pigeon-Inspired Optimization Based MPPT Technique for PV Systems. Processes 2020, 8, 356. [CrossRef]

37. Chen, Y.-K.; Hsu, H.-W.; Song, C.-C.; Chen, Y.-S. High-Flexibility MPPT Techniques with Communication Scan Network for PV Micro-Grid System. Processes 2022, 10, 117. [CrossRef] 
38. Ali, H.G.; Arbos, R.V.; Herrera, J.; Tobón, A.; Restrepo, J.P. Non-Linear Sliding Mode Controller for Photovoltaic Panels with Maximum Power Point Tracking. Processes 2020, 8, 108. [CrossRef]

39. Das, D.; Madichetty, S.; Singh, B.; Mishra, S. Luenberger Observer Based Current Estimated Boost Converter for PV Maximum Power Extraction-A Current Sensorless Approach. IEEE J. Photovolt. 2019, 9, 278-286. [CrossRef] 